\title{
Pengaruh Pembelajaran Berbasis Information and Communication Technology (ICT) terhadap Hasil Belajar Geometri Peserta Didik Kelas X SMK Kebangsaan Indonesia Maros
}

\author{
Rezky Amaliah', Rahmawati ${ }^{2}$, A. Muhajir Nasir ${ }^{3}$ \\ 1) SMAS PGRI Maros Baru \\ 2) 3) Program Studi Pendidikan Matematika, FKIP Universitas Muslim Maros \\ 1) kikiamaliah93@gmail.com \\ 2) nyoled@umma.ac.id \\ 3)amuhajirnasir@umma.ac.id
}

\begin{abstract}
ABSTRAK
Masalah dalam penelitian ini adalah rendahnya hasil belajar peserta didik kelas X SMK Kebangsaan Indonesia Maros pada materi geometri yakni 30 peserta didik (51,72\%) dari 58 peserta didik yang belum memenuhi kriteria ketuntasan minimal (KKM) yang telah ditentukan yaitu 75 . Peserta didik masih kesulitan memvisualisasikan dan mengeksplorasi bangun tiga dimensi dikarenakan mereka hanya menghafal karakteristik bangun tersebut. Tujuan penelitian ini adalah untuk mengetahui ada tidaknya pengaruh hasil belajar peserta didik setelah diajar dengan menggunakan pembelajaran berbasis Information and Communication Technology (ICT) dalam hal ini aplikasi geogebra pada materi geometri. Populasi dalam penelitian ini adalah kelas X SMK Kebangsaan Indonesia Maros. Sampel diambil sebanyak 26 orang dari 58 peserta didik dengan menggunakan teknik sampling purposive. Pengumpulan data menggunakan tes hasil belajar dalam hal ini yang dinilai adalah aspek pengetahuan. Pengujian prasyarat analisis menggunakan uji normalitas. Teknik analisis data yang digunakan adalah Paired Sample t-test. Hasil analisis data menunjukkan bahwa rata-rata nilai Pretest 42,73 dengan standar deviasi 8,784 sedangkan rata-rata nilai Posttest 81,61 dengan standar deviasi 6,788. Rata-rata skor gain ternormalisasi 0,69 dari data hasil belajar termasuk kategori sedang. Berdasarkan Uji-t, diperoleh nilai signifikansi $0,000<$ dari $\frac{1}{2} \alpha$ yaitu 0,025 yang berarti ada pengaruh hasil belajar matematika peserta didik setelah diajar menggunakan pembelajaran berbasis Information and Communcation Technology (ICT) pada materi geometri, tes akhir juga memperlihatkan bahwa 23 dari 26 peserta didik (88,46\%) telah mencapai KKM mata pelajaran matematika di SMK Kebangsaan Indonesia Maros.
\end{abstract}

Kata Kunci: Information and Communication Technology (ICT), Geogebra, Hasil Belajar Geometri

\begin{abstract}
The problem in this research contents is about low of study result of tenth grade students of SMK Nationality Indonesia Maros in geometry material with 30 students $(51,72 \%)$ from 58 students who unqualified the minimun criteria of mastery which it was determined is 75 . The students still difficulty to visualize and explore of the three dimensions figure because they only memorize the characteristic of the figure. The purpose of this research is to find out there is no influence taught by learning based on Information and Communication Technology (ICT) which use geogebra aplication in geometry material. The population of this research are tenth grade students of SMK Nationality Indonesia Maros. The sample taken with 26 people from 58 students with use purposive sampling technique. The accumulation of information use test of the result study which scored by cognitive aspect. The test of prerequisite analysis using the normality test. Data analysis technique which used is paired sample T-Test. The result of data analysis detect that average value of pretest 42,73 with deviation standard 8,784 while average value of posttest 81,61 with deviation
\end{abstract}


standard 6,788. Average score to normalitation 0,69 from data of result study in medium category. On t-test, the calculation of significance value is $0,000<$ from value $\frac{1}{2} \alpha$ at 0,025 , which there was an influence of result study mathematics if students was taught use learning based Information and Communication Technology (ICT) on geometry material, the last test also detect that 23 from 26 students $(88,46 \%)$ have taken the minimum criteria of mastery on mathematic in SMK Nationality Indonesia Maros.

Keywords: Information and Communication Technology (ICT), Geogebra, Geometry Study Result.

\section{A. PENDAHULUAN}

Pembelajaran matematika dianggap sebagian peserta didik merupakan pelajaran yang sulit. Hal ini disebabkan masih rendahnya minat belajar peserta didik untuk mempelajari matematika, bisa dikarenakan materinya yang dianggap sulit atau bahkan dari bahan ajarnya yang membuat sulit peserta didik. Berbagai cara sudah banyak dikembangkan oleh para peneliti untuk mengatasi masalah tersebut, mulai dari mengubah metode pembelajaran tradisional menjadi pembelajaran yang kooperatif maupun mengembangkan perangkatnya.

Saat ini dengan perkembangan teknologi informasi yang semakin pesat, maka menuntut dunia pendidikan untuk selalu menyesuaikan perkembangan teknologi terhadap usaha dalam peningkatan mutu pendidikan. Perubahan akan tuntutan itulah yang menjadikan dunia pendidikan memerlukan inovasi dan kreativitas guru dalam pelaksanaan proses pembelajaran dengan mengembangkan sistem pembelajaran yang berbasis teknologi, berorientasi pada peserta didik, dan memfasilitasi kebutuhan peserta didik dengan pembelajaran yang menantang, aktif, kreatif, inovatif, efektif, serta menyenangkan dengan mengembangkan kegiatan pembelajaran berbasis komputer.
Untuk dapat mengakomodasi tuntutan perkembangan zaman dalam kegiatan pembelajaran matematika, salah satu caranya dengan memanfaatkan media berbasis Information and Communication Technology (ICT).

Geometri merupakan cabang matematika yang objek-objek kajiannya sering dikaitkan dengan kehidupan sehari-hari, dan nyatanya dalam proses pembelajaran peserta didik sering menghadapi permasalahan. Menurut Strutchens, Harris dan Martin (2001) dalam Nooraini (2004:168) peserta didik mempelajari geometri tidak dengan mengeksplorasi dan menyelidiki konsep-konsep geometri melainkan dengan menghafalkan sifat-sifat objek geometri. Pengertian geometri seperti ini sangat terbatas dan dangkal, sebagai contoh ketika peserta didik hanya menghafal bahwa persegi memiliki empat sisi yang sama panjang, dia tidak akan bisa membedakan antara persegi dan belah ketupat. Akibatnya pesera didik tersebut sangat terbatas kemampuannya dalam pemecahan masalah.

Permasalahan dalam pembelajaran geometri khususnya bangun ruang dimensi tiga berkaitan dengan cara peserta didik mengkontruksi bangun ruang geometri, seperti diungkapkan Kariadinata (2010:11) bahwa dalam pemecahan masalah bangun ruang dimensi tiga diperlukan 
visualisasi, tetapi peserta didik kesulitan dalam mengkontruksi bangun ruang yang dimaksud, hal ini dikarenakan rendahnya kemampuan peserta didik memahami sifat-sifat keruangan, dan menafsirkan gambar-gambar dua dimensi.

Mengatasi permasalahan diatas, secara teori pembelajaran geometri menurut Brunner dalam Dahar (2006:787) harus melalui tiga tahap yaitu: enaktif, ikonik, dan simbolik. Menurut Hiele dalam Abdussakir (2009) dalam pembelajaran geometri harus disesuaikan dengan tahap perkembangan berpikir yaitu : tahap visualisasi, tahap analisis, tahap deduksi formal, tahap deduksi dan tahap rigor. Kedua teori tersebut mengisyaratkan bahwa dalam pembelajaran geometri harus dimulai dengan memperlihatkan objek-objek nyata secara langsung, baik berupa benda masif maupun menggunakan komputer, kemudian dilanjutkan dengan tahapan berikutnya sesuai dengan teori tersebut.

Peran teknologi dan media dalam pembelajaran geometri terletak dalam visualisasi. Beberapa pendidik matematik Chong (2001), Del Grande (1987), Kor (1995), Young (1987), Usiskin (1987) merekomendasikan memperbanyak aktivitas visual di kelas untuk membantu peserta didik memahami konsep geometri (Noraini, 2004:170). Organisasi pendidikan National Council of Teacher of Mathematic menetapkan teknologi sebagai satu diantara enam prinsip matematika sekolah, yaitu teknologi sangat penting dalam proses pembelajaran matematika, berpengaruh terhadap matematika yang diajarkan dan melibatkan peserta didik untuk belajar (NCTM, 2000:11).

Salah satu aplikasi atau program komputer yang dapat dimanfaatkan sebagai media pembelajaran matematika khususnya berkaitan dengan materi-materi geometri adalah Geogebra dikembangkan oleh Markus Hohenwarter yang merupakan aplikasi dinamis dan tidak berbayar sehingga dapat digunakan oleh siapa saja termasuk peserta didik. Geogebra sangat bermanfaat untuk mendemonstrasikan dan memvisualisasikan konsep-konsep matematika terutama objek geometri (Mahmudi, 2011).

Pada observasi yang telah dilakukan di SMK Kebangsaan Indonesia Maros penggunaan media pembelajaran ICT sudah diterapkan, peserta didik pun lebih cepat memahami materi yang disampaikan oleh guru. Namun hasil belajar peserta didik kelas X SMK Kebangsaan Indonesia Maros pada materi geometri yakni 30 peserta didik $(51,72 \%)$ dari 58 peserta didik yang belum memenuhi kriteria ketuntasan minimal (KKM) yang telah ditentukan yaitu 75 , di kelas $X$ peserta didik masih kesulitan memvisualisasikan dan mengeksplorasi bangun tiga dimensi dikarenakan mereka hanya menghafal karakteristik bangun tersebut. Oleh karena itu peneliti ingin menerapkan pembelajaran matematika berbasis ICT yaitu aplikasi geogebra untuk memudahkan peserta didik dalam memecahkan masalah-masalah dalam materi geometri. 
Berdasarkan deskripsi teori dan permasalahan yang telah diuraikan diatas, maka peneliti menganggap perlu melakukan penelitian yang berkaitan dengan pengaruh pembelajaran berbasis Information and Communication Technology (ICT) terhadap hasil belajar geometri pada peserta didik kelas X SMK Kebangsaan Indonesia Maros.

\section{B. METODE PENELITIAN}

\section{Jenis dan Desain Penelitian}

Jenis penelitian ini adalah penelitian PreExperimental. Rancangan penelitian ini berbentuk One Group Pretest-Posttest Design dengan menggunakan perlakuan pada objek penelitian dengan melibatkan satu kelas saja sebagai kelas eksperimen tanpa variabel kontrol. Perlakuan yang dimaksud adalah pengguaan model pembelajaran berbasis ICT dalam mengajar. Sebagaimana disajikan pada Tabel berikut.

Tabel 1. Rancangan Penelitian Pre-

\begin{tabular}{c|c|c}
\multicolumn{3}{c}{ Eksperimental } \\
\hline Tes Awal & Perlakuan & Tes Akhir \\
\hline T1 & $\mathrm{X}$ & T2 \\
\hline
\end{tabular}

(Nasir, A. Muhajir. 2013)

Keterangan :

T1 : Tes awal (Pretest), tes sebelum perlakuan

T2 : Tes akhir (Posttest), tes setelah perlakuan

X : Pembelajaran berbasis ICT.

Prosedur :

a. Kenakan $T_{1}$, yaitu pretest, untuk mengukur mean pemahaman konsep geometri sebelum subjek diajar dengan menggunakan model pembelajaran berbasis ICT. b. Kenakan subjek dengan $X$, yaitu model pembelajaran berbasis ICT.

c. Berikan $\mathrm{T}_{2}$, yaitu posttest, untuk mengukur mean pemahaman konsep geometri setelah subjek dikenakan variabel eksperimental X.

d. Bandingkan $T_{1}$ dan $T_{2}$ untuk menentukan seberapakah perbedaan yang timbul, jika sekiranya ada, sebagai akibat dari digunakannya variabel eksperimental X.

e. Terapkan test statistik yang cocok dalam hal ini t-test untuk menentukan apakah perbedaan itu signifikan.

\section{Waktu dan Tempat Penelitian}

Penelitian ini dilaksanakan pada semester genap tahun pelajaran 2020/2021 tepatnya pada bulan Agustus - November 2020.

Penelitian ini di laksanakan di SMK Kebangsaan Indonesia Maros yang beralamat di jalan Dr. Ratulangi No. 54, Pammelakkang Je’neAlepolea, Kabupaten Maros.

\section{Populasi dan Sampel Penelitian}

Populasi pada penelitian ini adalah peserta didik kelas X SMK Kebangsaan Indonesia Maros yang berjumlah 58 orang.

Sampel adalah sebagian atau wakil dari populasi yang akan diteliti. Adapun teknik pengambilan sampel dalam penelitian ini adalah dengan menggunakan teknik sampling purposive yaitu teknik penentuan sampel dengan pertimbangan tertentu (Sugiyono, 2009: 124). Pada teknik ini, penarikan sampel dari populasi tidak menggunakan dasar peluang tapi ditentukan oleh peneliti berdasarkan 
kebutuhannya (Nana Sudjana \& Ibrahim, 1989: 85-86).

Sampel yang digunakan pada penelitian ini adalah satu kelas dari kelas X SMK Kebangsaan Indonesia Maros yaitu kelas X.2 yang menggunakan pembelajaran berbasis ICT yang berjumlah 26 orang peserta didik.

\section{Variabel}

Variabel bebas (Variabel Independen) merupakan variabel berpengaruh yakni pembelajaran matematika berbasis ICT.

Variabel terikat (variabel dependent) merupakan variabel yang dipengaruhi yakni hasil belajar geometri peserta didik.

\section{Prosedur Pelaksanaan Penelitian}

Pelaksanaan penelitian ini melalui beberapa tahapan, yaitu :

\section{a. Tahap Persiapan}

Tahap persiapan ini merupakan tahap awal yang dipersiapkan dalam penelitian sebelum melakukan observasi mengenai perihal yang akan ditelitinya. Tahap persiapan ini meliputi: (1) Observasi lingkungan dan materi penelitian. (2) Menentukan materi penelitian. (3) Melakukan kajian teori tentang penelitian. (4) Menentukan populasi dan sampel penelitian. (5) Mengurus perijinan penelitian.

b. Tahap Pelaksanaan

- Tahap Pretest

Pretest yaitu tahap awal yang diberikan sebelum pelajaran dimulai. Pretest ini diberikan kepada peserta didik sebelum adanya perlakuan menggunakan pembelajaran berbasis ICT dengan menggunakan aplikasi geogebra sehingga diketahui sejauh mana pemahaman peserta didik pada materi geometri.

- Tahap Pembelajaran

Tahap pembelajaran ini adalah tahap yang menjadi acuan dalam penelitian ini. Kelompok eksperimen dalam kegiatan belajar mengajarnya menggunakan treatment berupa pembelajaran matematika berbasis ICT dengan menggunakan aplikasi geogebra untuk penyampaian materinya.

- Tahap Postest

Tahap terakhir dalam proses pembelajaran ini yaitu pemberian posttest. Posttest diberikan untuk mengetahui hasil belajar geometri peserta didik setelah proses pembelajaran berbasis ICT.

c. Tahap Evaluasi dan Pembuatan Laporan

Tahap evaluasi yaitu tahapan penelitian mengenai pengolahan data terhadap hasil belajar geometri peserta didik. Dalam tahap evaluasi ini akan diketahui apakah pembelajaran berbasis ICT ini dapat mempengaruhi hasil belajar peserta didik.

\section{Teknik Pengumpulan Data}

Suharsimi Arikunto (1997: 138) menjelaskan bahwa "alat evaluasi atau pengumpulan data secara garis besar dapat dibedakan menjadi dua, yaitu tes dan non tes". Teknik pengumpulan data yang dilakukan pada penelitian ini adalah dengan menggunakan pretest dan posttest. Tes dilaksanakan dua kali, yaitu sebelum (pretest) 
dan sesudah (posttest) peserta didik diberikan perlakuan (treatment) yaitu proses pembelajaran berbasis ICT dengan menggunakan aplikasi geogebra di dalam kelas untuk mengetahui hasil belajar peserta didik.

Instrumen yang digunakan dalam penelitian ini adalah tes tertulis sebanyak 5 butir soal. Soal itu digunakan pada pretest dan posttest adalah untuk mengetahui pengaruh pembelajaran berbasis ICT terhadap hasil belajar geometri peserta didik setelah mendapatkan perlakuan.

\section{Teknik Analisis Data}

Data hasil belajar peserta didik dikumpulkan melalui pemberian tes. Tes diberikan 2 kali, yaitu sebelum proses pembelajaran berlangsung (pretest) dan setelah proses pembelajaran (posttest). Tes yang diberikan adalah tes yang telah divalidasi.

Adapun teknik analisis data yang digunakan adalah sebagai berikut :

\section{a. Statistik Deskriptif}

Statistik deskriptif digunakan untuk mendeskripsikan karakteristik responden antara lain berupa mean, median, modus dan standar deviasi responden baik sebelum dan sesudah diberikannya perlakuan. Selain mendekripsikan hasil belajar peserta didik, dalam penelitian ini akan dideskripsikan bagaimana perbedaan yang terjadi sesudah peserta didik diberikan perlakuan. Perbedaan tersebut akan ditinjau berdasarkan perhitungan nilai gain ternormalisasi. Nilai gain ternormalisasi dalam penelitian ini diperoleh dengan membagi skor gain (selisih posttest dan pretest) dengan selisih antara skor maksimal dengan skor pretest. Perhitungan Nilai Gain ternormalisasi tersebut berdasarkan pendapat Hake (Maknun, 2007). secara matematis dengan rumus sebagai berikut.

$$
\begin{aligned}
G & =O_{2}-O_{1} \\
<g> & =\frac{O_{2}-O_{1}}{S M-O_{1}}
\end{aligned}
$$

Rumus tersebut digunakan untuk menghitung gain ternormalisasi dari perbedaan yang terjadi pada hasil belajar matematika peserta didik materi pokok geometri (titik dan garis) keterangan sebagai berikut:

$$
\begin{aligned}
\mathrm{G} & =\text { gain (selisih) } \\
<\mathrm{g}> & =\text { gain yang ternormalisasi } \\
\mathrm{O} 1 & =\text { skor pretest } \\
\mathrm{O} 2 & =\text { skor posttest } \\
\mathrm{SM} & =\text { skor maksimal }
\end{aligned}
$$

Skor gain normal yang diperoleh diinterpretasikan untuk menyatakan kriteria peningkatan yang terjadi dan sebagai data variabel yang akan digunakan pada pengujian hipotesis penelitian. Adapun acuan kriteria gain yang sudah dinormalisasikan menurut Hake, disajikan pada tabel di bawah ini.

Tabel 2. Kategori Gain yang Ternormalisasi

\begin{tabular}{cl}
\hline Interval & Kategori \\
\hline$<\mathrm{g}>0,70$ & Tinggi \\
\hline $0,30<<\mathrm{g}><0,70$ & Sedang \\
\hline$<\mathrm{g}>\leq 0,30$ & Rendah \\
\hline
\end{tabular}

\section{b. Statistik Inferensial}

Statistika inferensial digunakan untuk menguji hipotesis penelitian dan uji prasyarat 
penelitian. Jenis analisis uji yang digunakan adalah :

- Uji Normalitas

Uji normalitas dimaksudkan untuk mengetahui apakah data yang diteliti berasal dari populasi yang berdistribusi normal atau tidak. Pada penelitian ini untuk uji normalitas digunakan program SPSS dengan prosedur berikut.

Hipotesis

HO : sampel berasal dari populasi yang berdistribusi normal

H1 : sampel berasal dari populasi yang tidak berdistribusi normal

Statistik Uji

Taraf signifikansi $(\alpha)$ adalah angka yang menunjukkan terjadinya kesalahan analisa.

Taraf signifikansi dalam penelitian ini adalah

$5 \%$ atau 0,05 .

\section{Keputusan Uii}

HO diterima apabila nilai sig pada uji Shapiro-

Wilk lebih dari tingkat alpha yang telah ditentukan (nilai $p>=0,05$ ).

- Uji Hipotesis

Setelah melakukan uji prasyarat, dilakukan uji hipotesis penelitian. Dalam penelitian ini digunakan analisis statistik paired samples t-test yang kaidah pengujiannya sebagai berikut.

$\mathrm{H}_{0}$ diterima jika : sig (2-tailed) $>\frac{1}{2} \alpha$

$H_{0}$ ditolak jika : sig (2-tailed) $\leq \frac{1}{2} \alpha$

(Sumber : Nasir, A Muhajir 2018).

\section{HASIL PENELITIAN}

\section{Deskripsi Hasil Belajar Peserta Didik}

Deskripsi hasil penelitian ini menggambarkan tentang hasil belajar peserta didik sebelum dan sesudah diberikan perlakuan. Data tes hasil belajar peserta didik baik pretest maupun posttest peserta didik yang diajar menggunakan pembelajaran berbasis Information and Communication Technology (ICT) pada materi geometri dalam pembelajaran matematika, secara lengkap dapat dilihat pada lampiran 1 dan hasil analisis deskriptifnya dapat dilihat pada lampiran 2. Untuk lebih jelasnya disajikan pada tabel berikut:

Tabel 3. Rekapitulasi Tes Hasil Belajar Matematika Peserta Didik

\begin{tabular}{lrr}
\hline & Pretest & Posttest \\
\hline Jumlah Sampel & 26 & 26 \\
\hline Nilai Terendah & 28 & 70 \\
\hline Nilai Tertinggi & 65 & 98 \\
\hline Mean & 42,73 & 81,61 \\
\hline Median & 41,50 & 80,00 \\
\hline Range & 37,00 & 28,00 \\
\hline Standar Deviasi & 8,784 & 6,788 \\
\hline Varians & 77,165 & 46,086 \\
\hline & (Sumber : Analisis Data, 2018)
\end{tabular}

Dari tabel 3, dapat dilihat bahwa skor hasil belajar matematika peserta didik setelah diajar dengan menggunakan pembelajaran berbasis Information and Communication Technology (ICT) mengalami perubahan yang positif. Hal tersebut dapat dilihat dari perubahan skor yang terjadi pada nilai terendah dari 28 menjadi 70; nilai tertinggi dari 65 menjadi 98; median dari 41,50 menjadi 80,00; serta rata-rata nilai kelas dari 42,73 menjadi 81,61 . Hal tersebut sesuai 
dengan nilai varians data yaitu nilai varians data pretest sebesar 77,165; sedangkan nilai varians data posttest sebesar 46,086 yang berarti bahwa data pretest lebih bervarian daripada data posttest.

Berdasarkan deskripsi hasil belajar peserta didik diatas, maka hasil belajar matematika peserta didik setelah diajar menggunakan pembelajaran berbasis Information and Communication Technology (ICT) pada kelas eksperimen dalam penelitian ini dapat dikatakan meningkat. Dengan kata lain, hasil belajar peserta didik sebelum diberi perlakuan berbeda dengan hasil belajar peserta didik setelah diberi perlakuan. Perbedaan tersebut menunjukkan adanya peningkatan prestasi belajar peserta didik.

Adapun untuk ketuntasan belajar peserta didik berdasarkan aturan yang telah ditetapkan oleh SMK Kebangsaan Indonesia Maros pada kelas $X$, peserta didik dikatakan tuntas pada mata pelajaran matematika apabila mencapai nilai kriteria ketuntasan minimal yaitu 75 . Setelah peserta didik diajar menggunakan pembelajaran berbasis Information and Communication Technology (ICT) terdapat 23

dari 26 peserta didik yang mencapai kriteria ketuntasan minimal. Dengan kata lain, ketuntasan belajar matematika peserta didik kelas yang diteliti mencapai $88,46 \%$.

Adapun tabel ketuntasan hasil belajar adalah sebagai berikut.

Tabel 4. Distribusi Tingkat Ketuntasan Hasil Belajar

\begin{tabular}{lcccc}
\hline \multirow{2}{*}{$\begin{array}{c}\text { Kategori } \\
\text { Ketuntasan }\end{array}$} & \multicolumn{2}{c}{ Tuntas } & \multicolumn{2}{c}{ Tidak Tuntas } \\
\cline { 2 - 5 } & Frek. & (\%) & Frek. & (\%) \\
\hline $\begin{array}{l}\text { Kelas } \\
\text { Eksperimen }\end{array}$ & 23 & 88,46 & 3 & 11,54 \\
\hline
\end{tabular}

(Sumber : Data Primer 2018)

\section{Uji Prasyarat Analisis Hasil Penelitian}

Uji prasyarat yang digunakan dalam menganalisis hasil penelitian ini adalah uji normalitas, dimana uji normalitas digunakan untuk mengetahui data yang digunakan berasal dari populasi yang berdistribusi normal atau tidak. Uji normalitas data yang digunakan dalam penelitian ini dilakukan dengan bantuan program aplikasi SPSS. Data berdistribusi normal jika nilai-p pada uji Shapiro-Wilk lebih dari alpha $(\alpha)$.

Hasil komputasi pengujian normalitas data selengkapnya terdapat pada lampiran 2 bagian Test of Normality. Rangkuman hasilnya disajikan pada tabel berikut:

Tabel 5. Hasil Uji Normalitas

\begin{tabular}{ccccc}
\hline Sumber & Nilai- $\boldsymbol{p}$ & $\boldsymbol{\alpha}$ & Keputusan & Kesimpulan \\
\hline Pretest & 0,249 & 0,05 & Nilai- $p>\alpha$ & Normal \\
\hline Posttest & 0,507 & 0,05 & Nilai- $p>\alpha$ & Normal \\
\hline
\end{tabular}

(Sumber : Analisis Data, 2018)

Berdasarkan hasil uji normalitas di atas, diperoleh nilai-p pada uji Shapiro-Wilk lebih dari 0,05 . Karena nilai-p (sig) lebih dari 0,05 maka dapat disimpulkan bahwa data dalam penelitian ini berasal dari populasi yang berdistribusi normal. 


\section{Hasil Pengujian Hipotesis}

Untuk uji hipotesis dalam penelitian ini digunakan paired samples t-test pada data pretest dan posttest. Uji-t dalam penelitian ini digunakan untuk mengetahui apakah pembelajaran berbasis Information and Communication Technology (ICT) memberikan pengaruh terhadap hasil belajar matematika peserta didik. Hasil komputasi pada pengujian ini dilakukan dengan bantuan SPSS dapat dilihat pada lampiran 2, berikut adalah hasil uji hipotesisnya:

Uji hipotesis ini digunakan untuk mengetahui apakah terdapat pengaruh hasil belajar matematika peserta didik setelah proses pembelajaran berbasis Information and Communication Technology (ICT). Rangkuman hasilnya dapat disajikan pada tabel berikut ini:

Tabel 4.4 Paired Sample T-Test

\begin{tabular}{ccc}
\hline Sumber & Nilai- $\boldsymbol{p}$ & Keputusan \\
\hline Pretest-Posttest & 0,000 & $\mathrm{H}_{0}$ ditolak \\
\hline & (Sumber : Analisis Data, 2018)
\end{tabular}

$\mathrm{H}_{0}$ : Tidak ada pengaruh hasil belajar matematika peserta didik yang signifikan setelah proses pembelajaran berbasis Information and Communication Technology (ICT) pada materi geometri.

$\mathrm{H}_{1}$ : Ada pengaruh hasil belajar matematika peserta didik yang signifikan setelah proses pembelajaran berbasis Information and Communication Technology (ICT) pada materi geometri.

Berdasarkan hasil analisis paired sample $t$ test pada tabel 4.4 diperoleh nilai sig (2-tailed) dengan nilai- $p=0,000<\frac{1}{2} \alpha=0,025$. Oleh karena nilai- $p$ lebih kecil dari 0,025 maka sesuai dengan kriteria pengambilan keputusan untuk uji hipotesis, dapat disimpulkan bahwa $\mathrm{H}_{0}$ ditolak. Artinya, ada pengaruh hasil belajar matematika peserta didik setelah proses belajar berbasis Information and Communication Technology (ICT) pada materi geometri.

\section{PEMBAHASAN}

Pada bagian pembahasan ini akan dibahas hasil penelitian mengenai hasil analisis deskriptif dan analisis inferensial hasil belajar matematika peserta didik. Pembelajaran berbasis Information and Communication Technology (ICT) memberikan pengaruh yang positif terhadap hasil belajar matematika peserta didik. Pengaruh tersebut dapat dijelaskan pada nilai rata-rata tes hasil belajar matematika yang diukur melalui pretest peserta didik sebelum diberi perlakuan dan posttest peserta didik setelah diberikan perlakuan, dimana nilai rata-rata pretest adalah 42,73 dan nilai rata-ratanya mengalami peningkatan menjadi 81,61 setelah proses pembelajaran selesai. Tes setelah proses pembelajaran tersebut memperlihatkan bahwa 23 dari 26 peserta didik $(88,46 \%)$ telah mencapai nilai KKM mata pelajaran matematika di SMK Kebangsaan Indonesia Maros yaitu 75. Peningkatan tersebut terjadi setelah pembelajaran berbasis Information and Communication Technology (ICT) dalam hal ini aplikasi geogebra diterapkan. 
Pembelajaran berbasis Information and Communication Technology (ICT) bertujuan untuk mempermudah pendidik dalam mengajar dan memudahkan peserta didik dalam menerima materi pembelajaran. Kelebihan dari Pembelajaran berbasis ICT adalah membuat peserta didik lebih mandiri dan responsif sebab dalam pelaksanaan proses pembelajaran dengan mengembangkan sistem pembelajaran yang berbasis teknologi, berorientasi pada peserta didik, dan memfasilitasi kebutuhan peserta didik dengan pembelajaran yang menantang, aktif, kreatif, inovatif, efektif, serta menyenangkan dengan mengembangkan kegiatan pembelajaran berbasis komputer. Karena dengan penggunaan model pembelajaran ini, peserta didik akan lebih memahami materi secara mendalam sehingga proses pembelajaran lebih bermakna. Hal ini terlihat ketika pendidik memberikan beberapa soal latihan, dan peserta didik mampu menjawab dan menjelaskan dengan baik. Dan ini merupakan suatu pemahaman konsep dan hasil belajar yang baik dalam pembelajaran.

Hal ini sesuai dengan pendapat Neneng Umiyatun (2015) dalam hasil penelitiannya yang berjudul "Pengaruh Pembelajaran Berbantuan Geogebra terhadap Pemahaman konsep Matematis Siswa" menyatakan bahwa pembelajaran berbasis Information and Communication Technology (ICT) yaitu aplikasi Geogebra dalam pembelajaran matematika dapat membuat peserta didik lebih aktif saat pembelajaran berlangsung dan juga peserta didik memiliki pengetahuan, sikap dan keterampilan yang baik. Hal senada juga dikemukakan oleh Hidayatul Qomariyah (2016) dalam penelitiannya yang berjudul "Pengaruh Penggunaan Media Pembelajaran Berbasis Information and Communication Technology (ICT) terhadap motivasi dan Hasil Belajar IPA kelas IV MI Miftahul Ulum Jarak Kulon Jogoroto Jombang", mendapatkan hasil penelitian yang menunjukkan bahwa pembelajaran berbasis Information and Communication Technology (ICT) memberikan peningkatan yang signifikan terhadap hasil belajar matematika peserta didik.

Berdasarkan uraian diatas, dapat disimpulkan bahwa pembelajaran berbasis Information and Communication Technology (ICT) pada kelas $\mathrm{X}$ SMK Kebangsaan Indonesia Maros dapat meningkatkan hasil belajar matematika peserta didik.

\section{E. PENUTUP}

\section{Kesimpulan}

Berdasarkan hasil analisis dan pembahasan yang telah dilakukan pada bab IV, maka peneliti mengambil kesimpulan rata-rata skor sampel pretest $(42,73)$ lebih kecil dari rata-rata skor sampel posttest $(81,61)$. Nilai signifikansi dari hasil analisis paired sample t-test adalah 0,000< $\frac{1}{2} \alpha=0,025$ yaitu $\mathrm{H}_{0}$ ditolak, yang artinya terdapat peningkatan yang signifikan.

Dari hal tersebut dapat dikatakan bahwa ada pengaruh hasil belajar matematika peserta didik pada materi geometri setelah diajar dengan pembelajaran berbasis Information and Communication Technology (ICT). 


\section{Saran}

Berdasarkan kesimpulan diatas dalam penelitian ini, maka peneliti mengemukakan beberapa saran sebagai berikut: (1) Diharapkan pembelajaran ini bisa diterapkan pada pokok bahasan yang lain, terlebih pada mata pelajaran lainnya untuk meningkatkan prestasi belajar peserta didik baik pada jenjang Sekolah Dasar, Sekolah Menengah Pertama maupun Sekolah Menengah Atas. (2) Diharapkan kepada pendidik yang ingin menggunakan pembelajaran berbasis Information and Communication Technology (ICT) dalam hal ini aplikasi geogebra agar menyampaikan penjelasan dengan bahasa yang lebih mudah dipahami terlebih dahulu kepada peserta didik sebelum menggunakan aplikasi tersebut. (3) Diharapkan kepada peneliti selanjutnya, untuk melakukan penelitian lanjutan agar dapat menyempurnakan kekurangan-kekurangan yang ada dalam penelitian ini. Dan juga diharapkan menggunakan pendekatan dan model pembelajaran yang sesuai dan lebih efektif dalam melakukan penelitian dengan pembelajaran berbasis Information and Communication Technology (ICT).

\section{DAFTAR PUSTAKA}

Abdussakir. (2009). Pembelajaran Geometri dan Teori Van Hiele. (online) http: Abdussakir.wordpress.com diakses 17 november 2017 pukul 21.52 .

Arikunto, Suharsimi. (1997). Prosedur Penelitian Suatu Pendekatan Praktik. Jakarta: Rineka Cipta.
Arsyad, Azhar. (2013). Media Pembelajaran. Jakarta: Rajawali Pers.

Dahar, R. W. (2006). Teori-teori Belajar. Jakarta : Erlangga.

Darsono, Max, dkk. (2002). Belajar dan Pembelajaran. Semarang : CV IKIP Semarang Press.

Dimyati dan Mudjiono. (2006). Belajar dan Pembelajaran. Jakarta: Rineka Cipta.

Dimyati dan Mudjiono. (2009). Belajar dan Pembelajaran. Jakarta: Rineka Cipta.

Hohenwarter, M. \& Fuchs, K. (2004). Combination of Dynamic Geometry, Algebra, and Calculus in the Software System Geogebra. Tersedia: www.Geogebra.org/publications/pecs_200 4.pdf.Diakses pada 17 november 2017 pukul 22.15.

Hamruni. (2010). Strategi Pembelajaran. Yogyakarta : PT Pustaka Insan Madani.

Husaini, U., \& Purnomo, S.A. (2006). Pengantar Statistika. Jakarta: PT. Bumi Aksara.

Jenny C. Aker, Christopher Ksoll and Travis J. Lybbert. The Impact of aMobile Phone Literacy Program on Educational Outcomes. ABC 123. Diakses pada 26 november 2017 pukul 21.05.

Kariadinata, R. (2010). Kemampuan Visualisasi Geometri Spasial Peserta Didik Madrasah Aliyah Negeri Kelas X Melalui software Pembelajaran Mandiri. Jurnal Edukasi Matematika. ISSN : 2087-0523, volume 1 nomor 2, Nopember 2010.

Keller, Kevin Lane. (1998). Brand Equity. The Handbook of Technology Management, ed. Richard Dorf. CRC Pres Inc.

Mahmudi, A. (2011). Pemanfaatan Software Aplikasi Geogebra dalam Pembelajaran Matematika. Makalah disajikan dalam 
seminar LPM Universitas Negeri Yogyakarta, Yogyakarta, 2011.

Nasir, A. Muhajir. (2017). Pengembangan Perangkat Pembelajaran Model Pengajaran Langsung yang Melibatkan Media Animasi. Jurnal Kompetensi, [S.I], v. 11, n. 1, p. 1-10. ISSN 1978-3264. Diakses pada 9 januari 2018 pukul 07.30.

Nasir, A. Muhajir. (2016). Statistik Pendidikan. Yogyakarta : Media Akademi.

Nasir, A. Muhajir. (2017). Peningkatan Hasil Belajar Statistika Melalui Model Pembelajaran Kooperatif Tipe Think Pair Square pada Mahasiswa Semeseter II Program Studi Pendidikan Matematika. Jurnal Kompetensi. 10.2 Hal. 61-66.

Nasir, A. Muhajir. (2013). Penerapan Media Animasi pada Materi Bangun Datar Segiempat dalam Pembelajaran Matematika Kels VII SMP. Thesis. Pasca Sarjana Universitas Negeri Makassar.

Nasution. (2012). Teknologi Pendidikan. Jakarta: Bumi Aksara.

NCTM. (2000). Principles and standards for School Mathematics. Virginia : The NCTM Inc.

Noraini. (2004). Teaching and Learning of Geometry : Problems and Prospects. Masalah pendidikan jilid 27, 165-178.

Partino, R, \& Idrus, M. (2009). Statistik Deskriptif. Yogyakarta: Safiria Insania Press.

Rusman. (2012). Belajar dan pembelajaran Berbasis Komputer. Bandung : PT Alfabeta.
Rusman. (2017). Belajar dan Pembelajaran. Jakarta : Prenamedia

Sahabuddin. (2007). Mengajar dan Belajar cetakan ketiga.Makassar: Badan Penerbit UNM.

Sudjana. (1989). Metode Statistika. Bandung: Tarsito.

Sudjana, Nana \& Ibrahim. (1989). Penelitian dan Penilaian Pendidikan. Bandung : Penerbit Sinar Baru.

Sugihartono, dkk. (2007). Psikologi Pendidikan. Yogyakarta : UNY Press.

Suherman, Erman. (2003). Strategi Pembelajaran Kontemporer. Bandung : UPI.

Sudjana, Nana. (2009). Penilaian Hasil Proses Belajar Mengajar. Bandung : Remaja Rosdakarya.

Sukardi. (2011). Metodologi Penelitian Pendidikan. Jakarta: PT. Bumi Aksara.

Surya, Muhammad. (2004). Psikologi Pembelajaran dan Pengajaran. Bandung: Pustaka Bani Quraisy.

Suryabrata, Sumadi. (2003). Metodologi Penelitian. Jakarta : PT. RajaGrafindo Persada.

Tamimuddin, Muhammad \& Nurul, Muda. (2013). Pemanfaatan ICT dalam Pembelajaran: Pemanfaatan Software Aplikasi Geogebra. Yogyakarta : PPPPTK Matematika. 